\title{
(RE)STANDARDIZACIJA V PRIMEŽU \\ NACIONALNE IDENTITETE: PRIMER \\ HRVAŠKEGA, SRBSKEGA, BOSANSKEGA IN \\ ČRNOGORSKEGA JEZIKA
}

\section{Vesna POŽGAJ HADŽI, Tatjana BALAŽIC BULC}

Filozofska fakulteta Univerze v Ljubljani

Požgaj Hadži, V., Balažic Bulc, T. (2015): (Re)standardizacija v primežu nacionalne identitete: primer hrvaškega, srbskega, bosanskega in črnogorskega jezika. Slovenščina 2.o, 3 (2): 67-94. URL: http://www.trojina.org/slovenscina2.o/arhiv/2015/2/Slo2.o_2015_2_o6.pdf.

V procesu jezikovne standardizacije imajo med različnimi funkcijami ključno vlogo funkcija združevanja, funkcija razdruževanja in funkcija prestiža. V prispevku je $\mathrm{v}$ središču pozornosti funkcija razdruževanja, ki zahteva redefiniranje statusa standardnih jezikov, pri čemer ima pomembno vlogo tudi politika. $\mathrm{V}$ takih primerih lahko pogosto govorimo o procesu restandardizacije ali, z drugimi besedami, o preoblikovanju jezika, ki je že standardiziran, vendar na nekoliko drugačnih temeljih. Rezultate takega procesa prikažemo v štirih jezikih naslednikih nekdanje srbohrvaščine, tj. hrvaščini, srbščini, bosanščini in črnogorščini, ki so bili po razdružitvi deležni različnih (potrebnih in nepotrebnih) jezikovnih sprememb (posebej na leksikalni in glasoslovni ravni) z izjemno simbolno vrednostjo. Vzroki za spremembe so tako zunanji (nova družbenopolitična ureditev) kot notranji (spremenjen odnos do sosednih standardnih jezikov, večje zanimanje za jezikovna vprašanja, strankarsko delovanje posameznih jezikoslovcev v okviru različnih inštitucij ipd.), v obeh primerih pa tesno povezani s političnimi strukturami.

Ključne besede: (re)standardizacija, funkcije standardnega jezika, hrvaški standardni jezik, srbski standardni jezik, bosanski standardni jezik, črnogorski standardni jezik 


\section{UVOD}

Na področju nekdanje Jugoslavije so družbeno-politični pretresi v 8o. letih in začetku 90. let prejšnjega stoletja privedli do razpada federativne države ter nastanka samostojnih državnih tvorb, posledično pa se je v novih družbenih okoliščinah spremenil tudi status jezikov. Največje spremembe je zagotovo doživela srbohrvaščina, ki je izginila iz konstitutivnih dokumentov in javnega življenja novonastalih držav, namesto nje pa so se pojavili njeni nasledniki hrvaški, srbski, bosanski in nekoliko kasneje še črnogorski jezik, ${ }^{1}$ ki so dobili status uradnih jezikov, kot standardni jeziki pa so se $\mathrm{v}$ procesu ponovnega vrednotenja tudi nekoliko preoblikovali. Burna dogajanja na področju jezikovne standardizacije so pritegnila pozornost številnih tako domačih kot tujih (socio)lingvistov z zelo različnimi, včasih celo popolnoma nasprotnimi pogledi na zastavljena jezikovna vprašanja. Ne glede na različna mnenja se večina jezikoslovcev strinja, da je v tem obdobju jezik (ponovno) postal simbol ohranjanja nacionalne identitete in nacionalne kulture. Vendar je moral najprej skozi proces restandardizacije, $v$ katerem je doživel (potrebne in nepotrebne) spremembe na različnih jezikovnih ravneh, $\mathrm{z}$ enim in edinim ciljem razlikovati se od jezika sosedov. V nadaljevanju bomo najprej opisali različne procese standardizacije, potem pa prikazali glavne značilnosti restandardizacije v omenjenih jezikih.

2 STANDARDIZACIJA, STANDARDNI JEZIK IN NJEGOVE FUNKCIJE

V prispevku izhajamo iz splošno znanega dejstva, da je standardizacija dolgotrajen proces, za katerega težko rečemo, kdaj se je začel, še teže pa, kdaj se bo končal. Ta proces razumemo, podobno kot npr. Haugen (1983), kot eno od oblik jezikovnega načrtovanja, ki ga tradicionalno sestavljata dve osnovni dejavnosti, tj. načrtovanje statusa in načrtovanje korpusa nekega jezika. V

\footnotetext{
${ }_{1}^{1}$ Jeziki so navedeni glede na trajanje standardizacijskih procesov, pri čemer imata hrvaščina in srbščina najdaljšo tradicijo, sledi bosanščina s 70-letno vmesno prekinitvijo in na koncu kot najmlajši standardni jezik še črnogorščina.
} 
raziskavi se omejujemo predvsem na načrtovanje korpusa.

Standardni jezik ima, kot pravi Garvin (1993: 44), v neki jezikovni skupnosti v prvi vrsti sporazumevalno vlogo, in to na vseh področjih kulturnega in intelektualnega življenja. Če na jezikovno skupnost gledamo kot na družbenopolitično entiteto, ima standardni jezik tudi simbolno vlogo, saj je pogosto simbol nacionalne identitete. Glede na simbolni pomen, ki ga ima standardni jezik v določeni jezikovni skupnosti, Garvin (1993: 47) loči pet funkcij: 1. funkcijo združevanja (angl. unifying function), ki omogoča združevanje jezikovne skupnosti kljub narečnim ali drugim jezikovnim razlikam; 2. funkcijo razdruževanja (angl. separatist function), ki jezikovni skupnosti omogoča potrjevanje drugačne identitete $\mathrm{v}$ primerjavi $\mathrm{z}$ drugimi skupnostmi in je pogosto povezana s političnimi tendencami po avtonomiji in samostojnosti; 3 . funkcijo prestiža (angl. prestige function), ki podeljuje večji ugled jezikovni skupnosti s standardnim jezikom oziroma posamezniku, ki ta standardni jezik obvlada; 4. funkcijo soudeležbe (angl. participatory function), ki jezikovni skupnosti omogoča rabo lastnega jezika za soudeležbo pri sodobnem svetovnem kulturnem in znanstvenem razvoju; 5. funkcijo referenčnega okvira (angl. frame-of-reference function), ki se nanaša predvsem na vprašanja jezikovne pravilnosti in jezikovne norme. ${ }^{2}$ Od teh so za našo raziskavo pomembne predvsem prve tri.

S funkcijama združevanja in razdruževanja je povezan pojem jezikovna lojalnost, ki se precej bolj odraža v standardnem jeziku neke jezikovne skupnosti kot v njenih narečnih ali nestandardnih variantah. Garvin (1993: 49) loči dve vrsti jezikovne lojalnosti. Na eni strani je pragmatična lojalnost, ki se nanaša na lastne sodbe o jezikovni izvrstnosti, na drugi pa čustvena lojalnost, ki je tesno povezana z razdruževalno funkcijo. $V$ tem primeru ima standardni jezik status nacionalnega zaklada, ki je najpomembnejši in najbolj cenjen del nacionalne dediščine.

2 Več o tem v Peti-Stantić in Langston (2013) in Mićanović (2006). 


\section{STANDARDIZACIJA ALI RESTANDARDIZACIJA?}

$\mathrm{V}$ času razdruževanja skupne države je tudi v jeziku dominirala funkcija razdruževanja, ki je zahtevala redefiniranje statusa standardnih jezikov $\mathrm{v}$ srednjejužnoslovanskem jezikovnem prostoru. Pri tem se je najprej spremenil status jezika, in to tako, da so dotedanje variante postale samostojni standardni jeziki in obenem tudi uradni jeziki v novonastalih državah, sam proces pa ni zahteval posebnih dejavnosti jezikovnega načrtovanja (za razliko od spreminjanja korpusa). Po osamosvojitvi posameznih držav so namreč omenjeni standardni jeziki doživeli "poseben proces ponovnega vzpostavljanja lastne standardnosti, ki ga je pogojeval družbeni kontekst, v katerem je imela politika, pa tudi prestiž zelo pomembno vlogo « (Peti-Stantić in Langston 2013: 94). Sprememba statusa jezika je posledično povzročila tudi delno preoblikovanje temeljev novih standardnih jezikov. Glede na to, da standardni jezik sestavljajo, kot pravita Peti-Stantić in Langston (2013: 99), narečna osnova ter knjižnojezikovna3 ali intelektualna nadgradnja, je v novonastalih okoliščinah narečna osnova ostala nespremenjena (osnova vseh štirih jezikov je novoštokavsko narečje), na novo pa je bila ovrednotena knjižnojezikovna ali intelektualna nadgradnja, ki je bila v prvotni standardizaciji po mnenju mnogih jezikoslovcev »napačno zastavljena « (Peti-Stantić in Langston 2013: 99). Pri tem sta bili največ sprememb deležni glasoslovna in leksikalna raven. Glede na to, da se v teh procesih poudarja predvsem pomembnost spremembe statusa jezika, torej simbolna funkcija jezika, težko govorimo o modernizaciji jezika (več o tem npr. Gorjanc in dr. 2015) in jezikovnih reformah oziroma o procesu standardizacije, kjer je v ospredju sporazumevalna funkcija, temu procesu precej bolj ustreza pojem restandardizacija, ki ga razumemo kot proces »preoblikovanja jezika, ki je že opravil postopek standardizacije na nekoliko drugačnih temeljih « (Peti-Stantić in Langston 2013: 99). V tem smislu lahko rečemo, da se je v bosanščini, hrvaščini in srbščini v zadnjem desetletju 20.

3 Po našem mnenju bi bil tu primernejši pojem normativna nadgradnja oziroma kodifikacija, ki ustreza funkciji referenčnega okvira. 
stoletja odvijal proces restandardizacije, v črnogorščini pa je ta proces še vedno aktualen. V nadaljevanju sledi prikaz problematike po posameznih državah.

\subsection{Hrvaška: hrvaški standardni jezik}

Med jeziki, nastalimi na novoštokavski narečni osnovi, je v 9o. letih največ sprememb doživel hrvaški standardni jezik. Normativne in paranormativne jezikovne spremembe so zajele predvsem dve jezikovni ravni: leksikalno in glasoslovno, na kar opozarjajo različni avtorji (gl. npr. Pranjković 2008: 84-93; Badurina 2015: 67). V prispevku se osredotočamo na leksikalno raven, ki je tudi sicer najbolj dovzetna za spremembe in/ali »inovacije«, na eni strani zaradi znotrajjezikovnih dejavnikov, ki na leksiko vplivajo dolgotrajno in neopazno, na drugi pa zaradi zunajjezikovnih in političnih dejavnikov, ki na leksiko vplivajo agresivno, hitro in v širši jezikovni skupnosti zelo opazno, celo v primeru, ko zajemajo obrobne dele leksike (Opačić 2014: 75).

Ustrezen izbor leksikalnih enot oziroma leksemov je bil v 9o. letih na Hrvaškem izjemno pomemben, saj imajo »pravi« leksemi velik simbolni naboj in utrjujejo hrvaško nacionalno identiteto (več o tem npr. Kordić 2010). Tako so bili govorci, ki so uporabljali ustrezno leksiko, označeni kot domoljubi, govorci, ki te leksike niso uporabljali, pa nenadoma niso govorili »čistega« hrvaškega jezika in so zato dobili različne "politične etikete«, od katerih so bile najhujše zagotovo komunajzar in jugonostalgik (Opačić 2014: 34), ali pa oznake, da nisi naš, ampak njihov (torej izdajalec). Zato so se govorci v svojem lastnem jeziku počutili nelagodno in se jim je celo zatikalo ob iskanju "prave« besede (Badurina 2015: 69). Pogosto se je dogajalo, da je sogovorec popravljal napake govorca ali pa se je govorec popravljal kar sam. Takšna situacija je tipična, ko govorimo v tujem jeziku, in je v literaturi označena kot strah pred tujim jezikom, v zgoraj opisanem primeru pa se upravičeno govori o strahu pred maternim jezikom (gl. npr. Opačić 2014: 32-44; Mihaljević-Djigunović in dr. 2005: 307-317). Skratka, pomembno je bilo, kako se govori, in ne, kaj se govori, izbira lekiskalne enote pa je postala »prvo sporočilo, oznaka identitete /.../ v prvi vrsti 
nacionalne in/ali politične (Granić 2013: 77).

$\mathrm{V}$ tem času so po političnem nareku vsiljeni številni leksemi, npr. radnik postane djelatnik, radno vrijeme postane djelatno vrïeme, zadaća postane uradak, prisutnost postane nazočnost, izvještaj postane izvješće, cjenik postane koštounik itd. (gl. npr. Pranjković 2008: 89-92; Opačić 2014: 8-14; Badurina 2015: 69-70). Glede na njihov različen (standardno)jezikovni status, Badurina (2015: 69-70) govori o treh skupinah leksemov. V prvo skupino prišteva hrvaške termine (zlasti vojaško, pravno in administrativno terminologijo), ki so čez noč absolutno prevladali v primerjavi z obdobjem pred 1990. letom. Avtorica tukaj navaja dva postopka: a) pomensko polarizacijo (npr. »crveni« pasoš postane putovnica), ki danes, če zanjo ne obstaja zunanjjezikovni dejavnik, ne obstaja več; b) revitalizacijo oziroma oživljanje posameznih leksemov, ki prevzamejo terminološki pomen, s čimer izgubijo pridih arhaičnosti in/ali historičnosti in spet postanejo del aktivne leksike (npr. županija, župan, kuna). Nekateri avtorji ta del leksike imenujejo oživljenke. V drugo skupino sodijo leksemi, ki so vsiljeni iz povsem nejezikovnih razlogov, čeprav so obstoječi leksemi povsem sprejemljivi, če ne celo boljši (prim. tudi Pranjković 2008: 90-91; Opačić 2014: 8-14; Badurina 2015: 69). Ta postopek se najbolj intenzivno dogaja pri splošni leksiki, kjer so nekateri leksemi pridobili absolutno prednost, npr. izvješće nam. izvještaj, podrijetlo nam. porijeklo, štovanje nam. poštovanje, perilica nam. stroj za pranje, postaja nam. stanica itd. V tretjo skupino sodijo leksemi, ki še naprej soobstajajo skupaj z internacionalizmi, ki se pogosteje uporabljajo kot termini. Tako bodo $\mathrm{v}$ pogovornem diskurzu in strokovnih jezikih leksemi, kot so npr. rezerva, faktor, avion, povsem običajni, medtem ko jih bodo v bolj izbranem stilu (odvisno od konteksta) zamenjali leksemi pričuva, čimbenik, zrakoplov (Badurina 2015: 70).

Vladajoče politične elite so na različne načine usmerjale razvoj hrvaškega jezika. Tako npr. časopis Jezik, ki ga izdaja Hrvaško filološko društvo, od leta 1993 prireja Natečaj za najboljšo hrvaško besedo, ki do sedaj še ni bila zapisana 
v nobenem slovarju hrvaškega jezika, z opombo, da imajo prednost zamenjave za anglizme. Leta $2006 \mathrm{npr}$. je v uredništvo prispelo kar 500 predlogov, od katerih jih je 47 prišlo v ožji izbor, zmagala pa je beseda uspornik, ki naj bi nadomestila metaforični izraz ležeći policajac oziroma anglizem hupser. V naslednjih letih so bile med zmagovalnimi besedami tudi naplatnica nam. naplatna kućica; opuštaonica nam. wellness, borkinja nam. žena borac, proširnica nam. stent ali žilni potporanj, osobnik nam. OIB (osobni identifikacijski broj), ispraznica nam. floskula, zatipak nam. tipfeler itd. Čeprav organizatorji zagotavljajo, da namen natečaja ni vsiljevanje novih skovank, je novogovor vsekakor vplival na hrvaški jezik.

Hrvaška jezikovna politika se je v 90. letih lotila tudi tujih besed, še posebej srbizmov, ki so »sovražnik, ki ne ogroža le manifestiranja nacionalne identitete, temveč tudi samo nacijo «, kot kritčno pravi Lučić (2007: 338). Zato je to obdobje idealno za objavljanje razlikovalnih slovarjev hrvaškega in srbskega jezika,4 slogovnih priročnikov in slovarjev odvečnih besed v hrvaščini, ki vneto opisujejo do tedaj »prepovedane« leksikalne razlike med hrvaščino in srbščino. Čeprav jih nekateri »politično primerni« jezikoslovci nadvse hvalijo, je večina teh del prav diletantskih (več o tem npr. Samardžija 1993/94: 128; Peti 2006: 526-528). Problematike leksikalnopomenskih razlik med hrvaščino in srbščino se namreč lotevajo precej nestrokovno. Večinoma se omejujejo na popis »prepovedanih « besed in priporočajo »bolj hrvaške« lekseme. V sklepnem delu članka o razlikovalnih slovarjih hrvaškega in srbskega jezika, objavljenih v 90. letih, in njihovi nezanesljivosti Peti (2006: 528) poudari, da bi razlike med tema dvema jezikoma bolje »prikazal navaden dvojezični slovar hrvaškega in srbskega jezika«. Po dvajsetih letih je objava takšnega slovarja izzvala

\footnotetext{
4 Razlikovalni slovarji (p)opisujejo leksikalne razlike v dveh jezikovnih standardih, ki izhajata iz iste narečne osnove. V hrvaščini in srbščini takšni slovarji nastajo od 20. stoletja, pri čemer obstajata dva temeljna leksikografska koncepta, ki odražata tudi različno pojmovanje standardnega jezika: na eni strani unitarni, ki razlike relativizira in jih želi prikriti, predvsem z namenom, da se ustvari enoten standardni jezik oziroma srbohrvaščina, na drugi strani pa koncept, ki je unitarnemu diametralno nasproten in utemeljuje obstoj dveh samostojnih standardnih jezikov, med drugim tudi s poudarjanjem razlik na leksikalni ravni. Več o tem npr. Peti (2006: 507-528).
} 
»medijski vihar«. Leta 2015 je namreč izšel Srpsko-hrvatski objasnidbeni rječnik M. Samardžije (2015), ki je, kot piše avtor v predgovoru, zgrajen po načelih dvojezične leksikografije $\mathrm{z}$ namenom, da pripadnikom hrvaške jezikovne skupnosti služi kot pojasnjevalno orodje, ki jim bo omogočilo bolj popolno, pravilno in celovito razumevanje leksike srbskega jezika.

Podobno vlogo kot zgoraj omenjeni priročniki, nastali v 90. letih prejšnjega stoletja, so imeli tudi jezikovni nasveti v medijih, npr. različne kolumne, radijske in televizijske oddaje ipd., kjer so potekale razprave predvsem o odnosu do drugih tujih jezikov (še posebej o odnosu med hrvaščino in srbščino), terminologiji, purizmu itd. (več o tem Peti-Stantić in Langston 2013: 243-267). Diskurz večine nasvetov lahko označimo kot ideološki. Glede na rezultate analize posameznih nasvetov, še posebej v priročniku M. Dulčića (vodje lektroske službe na Hrvaškem radiu) Govorimo hrvatski, Peti-Stantić in Langston (2013: 247-253) skleneta, da je stališče avtorjev večinoma preskriptivno, zavzemajo se za izbiro »boljše« ali »pravilnejše« besede oziroma jezikovne oblike, pri čemer je najpomebnejši kriterij »hrvaškost «, priporočajo oblike, ki so tipične za hrvaški jezik, ker so »stare in dobre«, »lepe«, »samo naše« itd. Celo pri leksemih, kjer se obe obliki pojavljata v hrvaščini, priporočajo »samo naše«. Tukaj je odlomek iz razprave porijeklo ali podrijetlo:

Ampak ta oblika je samo naša. Zdaj, ko lahko prosto izbiramo in se odločamo, kaj nam bolj ustreza, ko lahko iz obilice leksikalnega fonda za normo izberemo tisto, kar je samo naše, in se po tem razlikujemo od vzhodnih sosedov - izberimo svoje. Torej podrijetlo (Dulčić, cit. po Peti-Stantić in Langston 2013: 250).

Na koncu moramo povedati, da funkcija omenjenih razlikovalnih slovarjev in slogovnih priročnikov pravzaprav ni »izobraziti javnost«, temveč so avtorji z njimi poskušali »dodati težo statusu hrvaščine kot samostojnega standardnega jezika /.../, težo že tako ali tako poudarjeni razdruževalni funkciji «(Peti-Stantić in Langston 2013: 104). Po našem mnenju so ta dela prinesla več škode kot koristi in zanetila številne nesporazume, in to ne le na Hrvaškem, ampak tudi na tujih univerzah. Njihovi predlogi $v$ jezikovni praksi v glavnem niso zaživeli 
in so sčasoma potonili v pozabo.

Hrvaško jezikovno politiko s konca prejšnjega stoletja označuje model purističnega jezikovnega načrtovanja, ki ga, kot pravi Lučić (2007), zaznamuje čustvena povezanost s cilji (utrjevanje nacionalne identitete in domoljubje), zanemarjanje resničnih potreb jezikovne skupnosti (simbolna funkcija jezika ima prednost pred sporazumevalno), poudarjanje jezikovnih posebnosti na vseh jezikovnih ravneh, preganjanje tujk in kvazisrbizmov itd. Kot smo lahko videli, imajo v propagiranju takšne jezikovne politike veliko vlogo mediji, ki so se polarizirali tako, da je bila izbira določene jezikovne enote odvisna od ideološke orientacije medija, kar kaže na politično dimenzijo jezikovnega purizma. Žal obstaja po letu 1991 zelo malo raziskav medijskega jezika, ki ne temeljijo na intuiciji, tistih nekaj (kot npr. Langston 1999; Czerwiński 2005 in dr.) pa kaže, da obstaja pomembna razlika med državotvornimi/nacionalističnimi in neodvisnimi/liberalnimi mediji; bolj ko je medij nacionalistično usmerjen, večja je verjetnost, da se udejanji puristična jezikovna politika. Vendar pa leksikalne spremembe niso bile ne hitre ne dosledne. Po besedah Peti-Stantić in Langstona (2013: 267), gre predvsem za spremembo pogostnosti uporabe posameznih oblik in ne za popolno zamenjavo obstoječih leksemov z novimi (ali oživljenimi), ki imajo v prvi vrsti simbolni pomen.

\subsection{Srbija: srbski standardni jezik}

Srbski standardni jezik je politično burna 9o. leta preživel dokaj mirno in varno. V teh letih je, kot poudarja Radovanović (2009: 206), »'srbščina' (p)ostala 'srbščina'«. Torej, za razliko od jezikovnih sprememb, ki so se dogajale v hrvaškem, bosanskem in nekoliko kasneje tudi v črnogorskem standardnem jeziku, se srbski standardni jezik na zunaj ni spremenil. $V$ družbi namreč ni bilo posebne potrebe po potrjevanju lastne identitete in nacionalnega imena $\mathrm{z}$ leksikalnimi, pravopisnimi in/ali kakršnimikoli drugimi razlikami glede na hrvaški jezik (Bugarski 2013: 98). Za razliko od Hrvaške, kjer so vladajoče 
politične elite nacionalizirale jezik s pomočjo različnih institucij (akademije, inštituta za hrvaški jezik, sveta za hrvaški jezik ipd.), so za srbski jezik in srbsko nacijo v Srbiji »skrbele« neformalne skupine. Vendar daleč od tega, da se v srbščini ni dogajala nacionalizacija jezika, gre le za drugačno vrsto nacionalizma. Kot pravi Bugarski (2012: 52), gre v Srbiji za »reduktivni tip nacionalizma, ki želi predvsem zagraditi in zavarovati lastno ozemlje«.

Družbeno-politična in vojna dogajanja so se v Srbiji odrazila v ideološko intoniranem in »napetem « javnem diskurzu (več o tem npr. Silaški in dr. 2009), birokratizaciji jezika (Klikovac 2008), različnih oblikah sovražnega govora (Jakšić 1996) itd. Ena najhujših oblik nacionalistične jezikovne ideologije se je pojavila $\mathrm{v}$ razglasu Slovo o srpskom jeziku tj. Jezičko zakonopravilo srpskog naroda, objavljenem leta $1998 \mathrm{v}$ šestih jezikih z naklado 300.000 izvodov, ki je $\mathrm{v}$ slavističnem svetu, pa tudi s strani srbskih jezikoslovcev doživel ostre kritike. V razglasu kar mrgoli neresničnih podatkov, kot je npr. ta, da sta umetnost in kultura Bošnjakov in štokavskih Hrvatov »tudi sestavni del srbske kulture«. Objava tega dokumenta je doživela ostro kritiko tudi v Srbiji, kar dokazujeta odloka št. 2 in 4 Odbora za standardizacijo srbskega jezika, ki naj bi ublažila škodljive posledice razglasa. 5

Razdruževalna funkcija pa se v srbskem standardnem jeziku kaže še na eni ravni. Za srbski standardni jezik je bila namreč značilna (danes uradno ne več) grafična dvojnost oziroma dvopisavnost, saj sta cirilica in latinica soobstajali kot enakovredni pisavi, kar je posebnost ne le v Evropi, temveč tudi v svetu (Radovanović 2009: 201). Spomnimo se, da je bila cirilica pred ustanovitvijo prve Jugoslavije (1918) edina tradicionalna srbska pisava, kasneje pa sta bili obe pisavi zakonsko enakopravni. Vendar je bila realnost nekoliko drugačna, saj pisavi pravzaprav nikoli nista bili v enakem položaju: latinica je nujna pri večini tujih jezikov, pri matematičnih formulah, spletnem sporazumevanju itd., zato je bila od 70. let raba latinice v Srbiji vse bolj pogosta. Razprave o odnosu

5 www.rastko.rs/filologija/odbor/odlukaoo2.html 
do latinice in cirilice so potekale že prej, vendar pa so po razpadu Jugoslavije dobile »novo preobleko «. ${ }^{6}$ Pričeli so se nacionalistični napadi na latinico (več o tem Požgaj Hadži 2014: 76-77), ki jo je bilo treba pregnati ne le iz uradne rabe, temveč tudi iz javne rabe glede na to, da se zasebne ne da nadzorovati. Skratka, pričel se je postopek recirilizacije (Mønnesland 2013: 247-348). Medtem ko so cirilico čuvali kot srbsko nacionalno svetinjo,7 je raba latinice pomenila »dokončno smrt že skrajno ogrožene cirilice, s tem pa tudi srbskega jezika in samega srbskega naroda « (Bugarski 2012: 53). Rezultat teh napadov je bila sprememba 10. člena Ustave Republike Srbije leta 2006, v katerem je zapisano: »V Republiki Srbiji je v uradni rabi srbski jezik in cirilska pisava. Službeno rabo drugih jezikov in pisav ureja zakon na temelju Ustave. $\ll^{8} \mathrm{~S}$ tem je latinica izgubila uradni status alternativne pisave, kar pa ni bilo v skladu z realnostjo. To potrjujejo tudi rezultati ankete iz leta 2002, ki jih navaja Klajn (cit. po Bugarski 2013: 96) in po katerih kar 39,8 \% anketiranih prebivalcev Srbije uporablja latinico, 21,9\% cirilico in 38,3\% obe pisavi. Podobna raziskava iz leta 2014 kaže, da nekaj več anketiranih piše v latinici (47 \%) in tudi nekaj več v cirilici (36\%), razen v Beogradu, kjer latinico uporablja kar 61,6 \% anketiranih. Po besedah Stevanović (2014) cirilica ne »umira « in je latinica ne ogroža, dokler je zapisana v Ustavi Republike Srbije in dokler so učbeniki natisnjeni v cirilici.

Kot lahko razberemo, srbski standardni jezik ni doživel večjih jezikovnih sprememb, torej se radikalizacija jezikovne politike ne dogaja v samem jeziku, temveč zunaj jezika, npr. med neformalnimi skupinami, posameznimi institucijami in nekaterimi jezikoslovci pri polemikah o odnosu med jezikom in nacijo. Pri vprašanju dvopisavnosti je večina razpravljalcev proti latinici (ki je v Srbiji sicer bolj prisotna od cirilice, zato jo je težko izkoreniniti iz zasebne in javne rabe) in za cirilico oziroma za njeno ohranjanje, predvsem z utemeljitvijo,

\footnotetext{
${ }^{6}$ Eden prvih jezikoslovcev, ki se je lotil tega vprašanja, je bil R. Marojević (več o tem Mønnesland 2013).

7 Omenimo npr. besedila na plakatih, napisana v cirilici: »Ostani Srbin i piši ćirilicom « ali "Srpska je samo ćirilica ( (Beograd 2007), ki jih v svoji knjigi o simbolih navaja Mønnesland (2013: 348).

8 Ustava Republike Srbije
} 
da je raba cirilice precej omejena, "popoln prehod na latinico pa bi pomenil odmik od srbske nacionalne in kulturne identitete, ki bi pustil daljnosežne negativne posledice« (Piper 2003: 130).

\subsection{Bosna in Hercegovina: bosanski/hrvaški/srbski standardni jezik}

Kot je iz zgornjega naslova razvidno, soobstajajo v Bosni in Hercegovini trije standardni jeziki, bosanski, hrvaški in srbski, zato lahko govorimo o multistandardnosti oziroma tristandardnosti (več o tem v Mønnesland 2005: 518-519). Preden podrobneje predstavimo jezikovno situacijo, moramo omeniti nekaj dejstev iz preteklosti, ki so pomembna za razumevanje današnjega (standardno)jezikovnega stanja v tej državi. Bosanščina je bila kot uradni jezik ukinjena z ukazom Deželne vlade avstro-ogrske monarhije leta 1907. Vendar tudi v novih družbenih okvirih, od ustanovitve prve Jugoslavije pa vse do 70. let prejšnjega stoletja Bosna in Hercegovina ni bila udeležena pri jezikovni standardizaciji srbohrvaščine na lastnih tleh, jezikovna politika je namreč potekala od zunaj: iz Zagreba in Beograda, pri čemer nihče ni upošteval bosansko-hercegovskih jezikovnih posebnosti (Šipka 2005: 431; Palić 2009: 113; Halilović 2014: 126). Ko je jugoslovanska jezikovna politika v 70. letih dojela, da je srbohrvaščina sicer skupni jezik, ne pa tudi enak, se je začelo govoriti o njeni variantnosti, natančneje o hrvaški in srbski varianti. V Bosni in Hercegovini so poskušali ohraniti enotno sporazumevalno področje, na katerem živi nacionalno zelo mešano prebivalstvo, obenem pa tudi promovirati posebnosti, povezane $\mathrm{s}$ tem prostorom, zato so tretjo varianto (nerodno) poimenovali bosanskohercegovski standardnojezikovni izraz (več o tem Palić 2009: 114; Katnić-Bakaršić 2013: 114; Halilović 2014: 125). S tem poimenovanjem je bila ustvarjena »skladna korelacija med simbolnim in sporazumevalnim « ali, z drugimi besedami, jezik je ohranil svojo avtentičnost in prepoznavnost $\mathrm{v}$ primerjavi $\mathrm{z}$ drugima dvema variantama oziroma nevtraliziral simbolne vrednote in jih izrabil $\mathrm{v}$ sporazumevalne in slogovne 
namene (več o tem Vajzović 2001: 90).

$\mathrm{Z}$ razpadom Jugoslavije in družbeno-političnimi spremembami v 9o. letih prejšnjega stoletja se je nekdanji bosansko-hercegovski standardnojezikovni izraz razcepil na tri standardne jezike: bosanski, hrvaški in srbski, 9 kar je zagotovo odraz simbolne funkcije jezika in družbeno-politične situacije. Politični akterji enačijo nacionalno identiteto z jezikovno identiteto, pri čemer jim jezik ponovno služi kot orodje za homogenizacijo in diferenciacijo. Oživlja se pregnani bosanski jezik, ki pa je rezerviran samo za Bošnjake (Palić 2009: 114), jezikovna politika za (bosansko-hercegovsko) hrvaščino in srbščino pa se še vedno izvaja od zunaj. Vprašanja, ki so povzročala in še danes povzročajo burne razprave, so povezana z naslednjimi temami: soobstoj treh standardov ali en standard; ime jezika: bosanski ali bošnjaški;io vprašanja (re)standardizacije vsakega jezika posebej; delovanje in enakopravnost vseh treh standardov v izobraževalnem sistemu, zakonodaji in medijih; jezikovno vedenje in jezikovna praksa znotraj posameznih jezikovnih skupnosti in med njimi (več o slednjem Vajzović 2001: 88-89) itd.

Oglejmo si primer izobraževanja v Bosni in Hercegovini, ki se izvaja v treh različnih standardih in vključuje še druge kulturno-zgodovinske specifike. Glede na to, da je jezik kot simbol nacionalne identitete prisoten v učnih načrtih in programih, učbenikih, strokovnem izpopolnjevanju učiteljev itd., so v Bosni in Hercegovini izbrali precej »nenavadno možnost, kako varovati jezikovne pravice učencev različnih nacionalnosti - v šolah ali celo razredih so jih ločili po nacionalnosti (več o tem npr. Mønnesland 2005: 505-517; Palić 2009: 120; Halilović 2014: 131-132). Ta fenomen bosansko-hercegovskega izobraževanja se imenuje »dve šoli pod eno streho«,11 kar je, kot že leta opozarjajo različni

\footnotetext{
9 Več o pravnih uredbah o uradnih jezikih gl. v Katnić-Bakaršić (2013: 119-124) in Halilović (2014: 127-129).

${ }^{10} \mathrm{~V}$ slovenščini se pojavljata obe poimenovanji, torej bosanski in bošnjaški jezik, vendar ima prvo poimenovanje precej višjo pogostnost.

${ }_{11}$ Temu vpašanju je posvečeno kar nekaj pozornosti v bosansko-hercegovskih medijih. Več o tem npr. Numanović (2012).
} 
avtorji (npr. Katnić-Bakaršić 2013: 124-125, Pašalić Kreso 2008: 67-88), eden hujših primerov nacionalistične politike v izobraževanju, ki pa, žal, še kar traja in traja.

Čeprav danes v Bosni in Hercegovini v sporazumevalnem smislu ni nikakršnih težav, je glavni problem razkorak med jezikovno stvarnostjo in idejo, kakšen naj bi po mnenju kreatorjev standardnojezikovne norme ta standard bil, ne upoštevajoč zgodovinskih, geografskih, kulturoloških itd. posebnosti bosansko-hercegovskega jezikovnega prostora. To dejstvo dobro ilustrira primer, ki ga navaja Palić (2009: 115): Hrvat iz Kiseljaka ${ }^{12}$ je po svojem jezikovnem izrazu precej bliže Bošnjaku iz Kiseljaka kot pa Hrvatu iz Hercegovine, da ne govorimo o Hrvatu s Hrvaške. Dejstvo je, da je v Bosni in Hercegovini obstajalo »nekakšno 'standardno' govorno in pisno sporazumevanje, značilno za pripadnike vseh njenih narodov « (Palić 2009: 115), in lahko bi rekli, da tudi danes obstaja. Zakaj je tako? Zato, ker govorci posameznih standardnih jezikov ves čas poslušajo »ne, kako bi bilo treba govoriti in pisati, temveč, kako morajo pisati in govoriti, če so Srbi, Hrvati, Bošnjaki« (Baotić 2001: 211), in da morajo v svoj jezik vključiti vse novosti, ki jih je uvedla norma, ali zavreči vse, kar je značilno za druga dva standardna jezika. Vse to je pri govorcih izzvalo zmedo in negodovanje, saj so se morali ponovno učiti lastni materni jezik, na drugi strani pa se v takšni situaciji niso znašli niti strokovnjaki, politiki itd.

Kot so že številni avtorji opozorili, v Bosni in Hercegovini ne obstaja nikakršna jezikovna politika, ne za posamezni standardni jezik ne skupna. Zato se (re)standardizacija vsakega od treh standardnih jezikov spopada $\mathrm{z}$ resnimi težavami, saj so središča še vedno zunaj države (Zagreb in Beograd) in bosansko-hercegovski Hrvati in Srbi nimajo nikakršnega vpliva na jezikovno politiko, ki se izvaja v njihovem imenu. Kar se tiče standardizacije bosanskega jezika, tj. jezika Bošnjakov, pravzaprav ni povsem jasno, kdo je odgovoren

\footnotetext{
${ }^{12}$ Kiseljak je mesto v Bosni in Hercegovini, pribl. 30 km severozahodno od Sarajeva.
} 
zanjo. Vse, kar je bilo do sedaj narejeno na tem področju, je namreč bolj sad entuziazma posameznih jezikoslovcev, brez kakršnekoli pomembnejše družbene podpore, predvsem pa brez jasno zadanega jezikovnopolitičnega okvira « (Palić 2009: 116-117). Ne glede na to, kot pravi Palić (2009: 117), lahko govorimo o treh različnih pristopih $\mathrm{k}$ standardizaciji bosanskega jezika $\mathrm{v}$ zadnjih 15 letih:13

a) Radikalni pristop, pri katerem stoji med jezikom in (bošnjaško) nacijo enačaj, torej jezik = (bošnjaška) nacija, in ki ima najmanj razumevanja za jezikovno stvarnost. Ves čas poudarja nefunkcionalno arhaizacijo (najpogosteje gre za orientalizacijo) bosanskega jezika (Mønnesland 2005: 502, Palić 2009: 117).

b) Zmerni pristop izhaja iz stališča, izrečenega $\mathrm{v}$ 1. točki Listine $o$ bosanskem jeziku, ki pravi, da je bosanski jezik »jezik Bošnjakov in vseh tistih, ki s tem imenom označujejo svoj jezik «, ${ }^{14} \mathrm{~s}$ čimer se jezik odpira k drugim nacionalnim skupnostim. Gre za strpno normo, v kateri se uveljavljajo tiste bošnjaške posebnosti, ki jih je norma nekdaj skupnega standarda zanemarjala (Palić 2009: 117).

c) Konformistični pristop, ki nadaljuje jezikovno politiko 70. in 80. let, pri čemer je bosanski jezik samo novo ime za bosansko-hercegouski standardnojezikovni izraz; norma je popolnoma odprta in brez posebnega odnosa ne le do nacionalnega, temveč tudi do regionalnega (Palić 2009: 117).

Čeprav je proces standardizacije bosanskega jezika nedokončan in omenjeni pristopi samo nakazujejo načelne normativne rešitve, lahko sklenemo, da je pri standardizaciji bosanščine prevladal zmerni pristop, ki ga je podprlo okoli 60 podpisnikov omenjene Listine o bosanskem jeziku (Palić 2009: 117).

\footnotetext{
13 Več o avtorjih, ki pripadajo posameznemu pristopu, gl. v Palić (2009).

14 Več o tem na spletni strani http://www.bir.ba/index.php/tekstovi-i-kolumne/item/2011povelja-o-bosanskom-jeziku (26. 12. 2015).
} 
Posebno vprašanje je hrvaški standardni jezik, ki se ga vsiljuje bosansko-hercegovskim Hrvatom »kot nacionalno svetinjo in glavni znak identitete«, čeprav je povsem drugačen od njihovega maternega jezika, kar deluje destruktivno na hrvaško kulturo v Bosni in Hercegovini (Lovrenović 2012: 3). Razen tega tudi na Hrvaškem ni splošnega konsenza o nekaterih normativnih pravilih. Kar se tiče hrvaščine v Bosni in Hercegovini, Lovrenović (2012: 7-8) predlaga tri možnosti: a) po inerciji prevzemati normativne rešitve iz Zagreba; b) »obdelati« specifično standardizacijo hrvaškega jezika glede na bosansko-hercegovsko jezikovno in kulturološko stvarnost; ali c) dogovoriti se o skupni bosansko-hercegovski standardizaciji, ki bi upoštevala nacionalno-jezikovne posebnosti, kar je, vsaj glede na trenutne razmere, bolj utopična možnost. Glede na to, da je standardizacija navadno bolj vprašanje politike kot jezikoslovja, bo tudi v tem primeru odločala politika. Skrajni čas bi že bil, da jezikovna politika hrvaškega standardnega jezika $\mathrm{v}$ Bosni in Hercegovini postane avtonomna in deluje $\mathrm{v}$ skladu s potrebami govorcev (Lovrenović 2012: 8).

Intenzivno jezikovnopolitično dogajanje poteka tudi pri vprašanju srbskega standardnega jezika v Bosni in Hercegovini, kjer se je proces restandardizacije pokazal v vseh svojih ekstremnih oblikah leta 1993 s političnim dekretom o uvajanju ekavice kot uradne variante jezika Srbov v Bosni in Hercegovini. ${ }^{15}$ Takšna odločitev je bila popolnoma v nasprotju z jezikovno stvarnostjo, saj na tem področju živijo govorci, ki poleg Črnogorcev sodijo v skupino najizrazitejših ijekavcev med štokavci na sploh (Pranjković 2008: 131). S tem so prebivalci dobili ukaz, naj pričnejo v imenu srbske enotnosti tako rekoč »čez noč« uporabljati ekavico, kar je izzvalo negotovost in zmedo v javnem komuniciranju in celo pri političnih vodjih, ki so odlok sprejeli (Požgaj Hadži in Balažic Bulc 2013: 338-339). Kot pravi Bugarski (1995: 130-131), ima ta odlok dva aspekta: na eni strani svojevrstno etnično čiščenje jezika, na drugi pa približevanje Srbiji ter vsiljevanje stereotipne formule, $\mathrm{v}$ kateri se pojma srbski in srbstvo

${ }_{15}$ Dekret je bil ukinjen z odlokom Ustavnega sodišča Republike Srbije leta 1998. 
povezujeta izključno s cirilico in ekavico. Pri tem se seveda pozablja na dvojnost srbskega standardnega jezika (soobstoj ekavščine in ijekavščine), kar je izzvalo številne nesporazume in prepire. Da bi se v prihodnje izognili takšnim razprtijam, Šipka (2006: 167) predlaga izdelavo Kodeksa rabe srbskega standardnega jezika, ki bi določal pravila za uporabo ekavskega in ijekavskega govora, prav tako cirilske in latinske pisave ter opredelil odnos do besedil, prevzetih iz hrvaškega in bošnjaškega jezikovnega standarda.

Če sklenemo, v Bosni in Hercegovini nihče ni zadovoljen s tristandardno jezikovno situacijo in s procesi restandardizacije, ki je še vedno obremenjena $\mathrm{z}$ zunajjezikovno realnostjo. Normativisti se ne morejo dogovoriti o skupni jezikovni politiki, ki za hrvaščino in srbščino še vedno poteka od zunaj in ne upošteva kulturno-zgodovinskih posebnosti bosanskohercegovskega prostora (težko je verjeti, da bo do dogovora sploh kdaj prišlo!), uporabniki jezika pa njihovih norm ne upoštevajo in nikakor nočejo spregovoriti $\mathrm{v}$ restandardiziranem jeziku, ki „po njihovem mnenju živi samo v jezikovnih priročnikih“ (Palić 2009: 118). S težavami, povezanimi z istočasno rabo vseh treh standardnih jezikov, pa se srečuje tudi celotna bosanskohercegovska skupnost, npr. pri vprašanjih skupnega šolskega in zakonodajnega sistema. Kljub vsemu med političnimi akterji ni zaznati želje po interkulturnem komuniciranju ter razumevanju Drugega in Drugačnega.

\section{4 Črna gora: črnogorski standardni jeziki}

Leta 2007 je postal po številnih debatah črnogorski jezik uradni jezik v Črni gori (več o tem Lakić 2013: 133-143). Za razliko od drugih standardnih jezikov v sosednih novonastalih državah je črnogorščina šele na začetku svoje poti (re)standardizacije, ki je, tako kot drugje v regiji, tudi v Črni gori predvsem politično in ne jezikovno vprašanje.

Da bo stvar bolj razumljiva, moramo uvodoma povedati, da je že pred razpadom Jugoslavije obstajalo nacionalistično gibanje za črnogorščino z glavnim akterjem V. Nikčevićem, ki je v svojih delih zahteval radikalne spremembe 
predvsem v smislu arhaizacije jezika. Vendar ker ni bil jezikoslovec, so se mu jezikoslovci predvsem posmehovali. Ko se leta 1994 v boj vključi črnogorski PEN z objavo Resolucije o črnogorščini kot uradnem jeziku v Črni gori, gibanje dobi politično podporo. Leta 2003 se gibanje z ustanovitvijo Inštituta za črnogorski jezik in jezikoslovje $\mathrm{v}$ Cetinju pod Nikčevićevim vodstvom institucionalizira, po njegovi smrti leta 2007 pa vodstvo prevzame A. Čirgić, ki nadaljuje z Nikčevićevimi idejami. Inštitut izvaja nacionalistično jezikovno politiko in je v neprestanem sporu z Univerzo v Črni gori. Da bi se zmanjšal vpliv univerzitetnih profesorjev, Vlada Črne gore leta 2010 ustanovi Inštitut za črnogorski jezik in književnost, ki ga vodi A. Čirgić, po štirih letih pa ga preoblikuje $\mathrm{v}$ znanstvenoraziskovalno in visokoizobraževalno ustanovo Fakulteto za črnogorski jezik in književnost »sa śedištem na Cetinju «.16 Vse te politične odločitve tudi uradno odprejo prosto pot za izvajanje Nikčevićeve nacionalistične jezikovne politike (več o tem Mønnesland 2013: 343-346).

Prvi korak k priznanju črnogorskega jezika je njegova (re)standardizacija. Zato je Vlada Črne gore leta 2008 ustanovila Svet za standardizacijo črnogorskega jezika ( $v$ nadaljevanju Svet) ${ }^{17} \mathrm{z}$ nalogo, da izdela predlog pravopisa, slovnice in slovarja črnogorskega standardnega jezika in da skrbi za uveljavljanje montenegristike. Vendar se je Svet že pri prvi nalogi (izdelava koncepta za pravopis črnogorskega jezika) razdelil v dve nasprotujoči si skupini: a) književno (ki meni, da je treba črnogorščino vrniti nazaj h koreninam in da jo je treba arhaizirati $\mathrm{z}$ uvedbo novih fonemov) in b) jezikovna (črnogorska varianta srbohrvaščine bi morala biti osnova za standardizacijo (Lakić 2013: 144-145, Glušica 2011: 272). Zaradi popolnoma nasprotnih stališč in nepremostljivih razlik v razumevanju črnogorskega standarda sta bili narejeni dve verziji pravopisa in v začetku leta 2009 oddani Ministrstvu za izobraževanje in znanost Črne gore (v nadaljevanju Ministrstvo). Strokovna javnost je

\footnotetext{
16 www.fcjk.me/

${ }_{17}$ Od 13 članov Sveta so bili samo štirje jezikoslovci, ena literarna teoretičarka, en novinar, en profesor filozofije in šest književnikov.
} 
pričakovala javno razpravo, vendar pa se to ni zgodilo. Ravno obratno. Svet počasi neha delovati, oblikuje pa se Ekspertna komisija (v nadaljevanju Komisija), ki naj bi ocenila obe verziji pravopisa in ki je julija 2009 predložila ministru za izobraževanje Pravopis črnogorskega jezika ${ }^{18} \mathrm{z}$ radikalnimi odmiki od obstoječe norme. Po letu dni je ista Komisija presenetila črnogorsko javnost in predstavila Slovnico črnogorskega jezika, ${ }^{19}$ ki jo je Ministrstvo razglasilo za uradno (Glušica 2011: 273).

Kot pravi Glušica (2011: 273), so temeljna izhodišča (re)standardizacije črnogorščine prevzeta po Nikčeviću in temeljijo na različnih nacionalističnih mitih, npr. na mitu o avtohtonosti in posebnosti, mitu o naciji žrtvi, mitu o naciji sovražniku in mitu o notranjih sovražnikih (več o tem Glušica 2010: 2933, Kordić 2010: 327-354). Vzrok za takšno politiko v Črni gori temelji na dojemanju jezika kot simbola nacionalne identitete, zato se govori o črnogorski nacionalistični jezikovni politiki, miti pa se ohranjajo tudi zaradi nevednosti. Kot primer lahko navedemo pravopisni »lajtmotiv« iz Nikčevićevih del, ki ga navaja Glušica (2010: 38-39): »Osnovni lajtmotiv črnogorskega pravopisa mora biti maksima: Piši kot pišejo dobri pisatelji! Naši najboljši pisatelji pa so: Petar I, Petar II Petrović Njegoš...«. Že dolgo je jasno, da jezik književnosti „deluje po »nareku « jezika kot sistema in ne po 'nareku' jezika kot standarda«, zato ne more biti 'vzor' standardnemu jeziku « (Silić 2006: 11).

Povsem očitno je, da želi črnogorska jezikovna politika ustvariti čim več razlik med črnogorskim standardnim jezikom in vsemi ostalimi jeziki, ki temeljijo na novoštokavski osnovi. Zato je restandardizacija črnogorščine prinesla ne le jezikovne spremembe, temveč tudi spremembe sistema. Glasoslovni sistem črnogorščine je bil namreč povečan za dva fonema: ś in ź, ki sta prevzeta iz črnogorskega ljudskega govora, npr. sjekira - śekira; zjenica - źenica (jotirane

\footnotetext{
18 Perović in dr. (2010)

19 Čirgić in dr. (2010)
} 
variante). $\mathrm{Ne}$ le, da sta fonema sporazumevalna ovira, ${ }^{20}$ njihovo uvajanje je poleg kulturnega šoka privedlo tudi k polarizaciji družbe: na eni strani so tisti, ki niso spremenili svojih pravopisnih in pravorečnih navad, na drugi pa tisti, ki »čez noč spremenijo svoj izraz, jotirane oblike pa služijo kot dokaz o politični in nacionalni ustreznosti ter pripadnosti« (Glušica 2010: 36). Ker jotirana varianta ni zaživela v javni besedi, je bila ob vsestranski pomoči Ministrstva implementirana v izobraževalni sistem. Kljub dejstvu, da glavni akterji jezikovne politike v Črni gori sprejemajo samo jotirano varianto (gl. npr. spletne strani Skupščine Črne gore), ${ }^{21}$ se ta novost sistematično ne uporablja ne v medijih, ne $\mathrm{v}$ administraciji in ne $\mathrm{v}$ šolstvu.

Na koncu lahko sklenemo, da proces restandardizacije črnogorskega jezika spremljajo številna vprašanja in diskusije o osnovnih vprašanjih načrtovanja statusa jezika (kar vključuje tudi vprašanje statusa srbščine, hrvaščine, bosanščine, albanščine in jezikov drugih manjšin v Črni gori) ter načrtovanja korpusa jezika. Aktualna jezikovna politika se izvaja s pozicije moči, pri čemer glavni akterji, tj. Vlada Črne gore s svojimi pristojnimi inštitucijami in nekaterimi jezikoslovci, vsiljujejo nacionalistični odnos do jezika, predvsem $\mathrm{s}$ poudarjanjem jezika kot simbola nacionalne identitete. Skratka, ko se govori o jeziku, je diskurz še vedno »na ravni nacionalnega romantizma« (Mønnesland 2009: 135), konstruktivna standardizacija črnogorskega jezika pa čaka boljše čase in morda nove generacije.

\section{NAMESTO ZAKLJUČKA: KONEC RESTANDARDIZACIJE?}

Zapletene družbeno-politične okoliščine, ki so nastale konec 80 . in v začetku

\footnotetext{
20 Da sta fonema resnično sporazumevalna ovira, dokazuje »zgodba «, ki jo pripoveduje Glušica (2010: 42) v članku z naslovom Črnogorski jezikv čeljustih nacionalizma, pri čemer uporablja besede in celo nadpomenke iz pravopisnega slovarja Pravopisa črnogorskega jezika. Začetek zgodbe se glasi: "Miśo pođekad šćaše beśjediti o nekijem śećanjima iz đetinjstva i o tome kako šśaše odbačiti svoj veleljepni pośed, inače nije imao pośedovni list, jer ga je śenjalo da će se negđe drugđe zauvar ućešit od toga đečjeg śećanja, zbog kojeg šćaše biti po vas dan śetan i neućešan./.../ « Tudi večina Črnogorcev bi imela težave z razumevanjem besedila.

${ }^{21}$ Skupščina Črne gore (www.skupstina.me/)
} 
90. let prejšnjega stoletja predvsem kot posledica zunajjezikovne stvarnosti, so se odrazile $\mathrm{v}$ jeziku in zunaj jezika. Jezik je bil v zadnjih dvajsetih letih v prvi vrsti simbol nacionalne identitete (njegovo ime, pisava, nekateri ideologemi itd.), s katero so različne politične elite promovirale svoje politične ideologije. $\mathrm{Z}$ razpadom Jugoslavije in nastankom novih držav se je začelo obdobje notranjega in zunanjega priznavanja jezikov (Škiljan 2008: 80), obenem pa tudi njihove restandardizacije, ki je pustila neizbrisno sled, predvsem $\mathrm{v}$ zadnjem desetletju 20. stoletja.

Kot smo videli, je v primerjavi z drugimi standardnimi jeziki, nastalimi na novoštokavski osnovi, največ »inovacij« doživel hrvaški standardni jezik, in to predvsem na leksikalni ravni, s čimer so se promovirali leksemi, ki so krepili hrvaško identiteto (»hrvaškost «), in na drugi strani »preganjali« celo nekateri lekseme, ki jih hrvaški normativni priročniki navajajo kot sinonime (npr. nekateri srbizmi, internacionalizmi ipd.). Za razliko od hrvaščine se v srbskem standardnem jeziku restandardizacija odraža predvsem $\mathrm{v}$ nacionalističnih napadih na latinico, ki naj bi pomenila »dokončno smrt že tako skrajno ogroženi cirilici, s tem pa tudi srbskemu jeziku in celo srbskemu narodu « (Bugarski 2012: 53). Jezikovno situacijo v Bosni in Hercegovini zaznamuje tristandardnost (Mønnesland 2005: 518-519), s tem da se jezikova politika za hrvaščino in srbščino izvaja od zunaj, brez upoštevanja bosanskohercegovskih značilnosti, standardizacija bosanskega jezika pa, po fazi pretiravanja in napačnih odločitev, dopušča soobstajanje dvojnic, kar je tudi pravi odraz bosanskohercegovske jezikovne stvarnosti (Halilović 2014: 129). Črnogorščina je šele na začetku poti (re)standardizacije, s številnimi težavami in nesoglasji, ki so predvsem politične narave. Jezikovne spremembe, ki jih prinašajo sodobni jezikovni priročniki, sicer temeljito posegajo v glasoslovni sistem, vendar je izbira prepuščena jezikovnim uporabnikom. In dejstvo je, da predlagane radikalne spremembe v črnogorski jezikovni praksi (še) niso zaživele.

Iz povedanega lahko sklenemo, da se v hrvaščini in srbščini restandardizacija normalizira, da v bosanščini obstaja vrsta nerazrešenih vprašanj, črnogorščina 
pa je šele na začetku svoje (re)standardizacije. Čeprav bi v zadnjih 20 letih novonastali standardi lahko samostojno zaživeli (zlasti hrvaščina in srbščina), se pričakovani »razcvet« po letih jezikovne unifikacije ni zgodil. Poleg tega težko rečemo, da kateri od teh jezikovnih standardov sploh sistematično izvaja kakršnokoli jezikovno politiko - jezikovno politiko, ki bi pustila ob strani »politizacijo « jezika in bi končno začela s sistematskim preučevanjem jezikov na podlagi raziskav tako s filološkega kot kulturološkega zornega kota. Dokler pa jezikovna pravila po lastni presoji kreira ena in edina avtoriteta, in to $\mathrm{s}$ pozicije moči, lahko tudi proces restandardizacije traja. 


\section{ZAHVALA}

Zahvaljujeva se anonimnima recenzentoma za koristne recenzentske komentarje ter urednikom za skrbno pregledovanje besedila.

\section{LITERATURA}

Badurina, L. (2015): Standardizacija ili restandardizacija hrvatskoga jezika u 90-im godinama 20. stoljeća. V T. Pišković, T. Vuković (ur.): Jezične, kulturne i književne politike: 57-79. Zagreb: Zagrebačka slavistička škola.

Baotić, J. (2001): Jezik u procesu integracije i dezintegracije društvene zajednice. V S. Mønnesland (ur.): Jezik i demokracija: 203-212. Sarajevo: Institut za jezik.

Bugarski, R. (21995): Jezik od rata do mira. Beograd: Slavograf.

Bugarski, R. (2012): Portret jednog jezika. Beograd: Biblioteka XX vek.

Bugarski, R. (2013): Jezička politika i jezička stvarnost u Srbiji posle 1991. godine. V V. Požgaj Hadži (ur.): Jezik između lingvistike i politike: 91111. Beograd: Biblioteka XX vek.

Czerwiński, M. (2005): Język - ideologija - narod: Polityka językowa w Chorwacji a język mediów. Kraków: Scriptum.

Čirgić, A., Pranjković, I., Silić, J. (2010). Gramatika crnogorskoga jezika. Podgorica: Ministarstvo prosvjete i nauke Crne Gore. Dostopno prekhttps://crnogorskapitanja.files.wordpress.com/2012/08/gramatika-crnogorskogajezika.pdf (13. 1. 2016).

Garvin, P. L. (1993): A conceptual framework for the study of language standardization. International Journal of the Sociology of Language 100/101: 37-54.

Glušica, R. (2010): Crnogorski jezik u čeljustima nacionalizma. Riječ, nova serija (4): 25-45. 
Glušica, R. (2011): O restandardizaciji crnogorskog jezika. Studii Slavistici 8: 271-278. Dostopno prek: http://torrossa.com/pages/ipplatform/itemDetails.faces (26. 12. 2015).

Gorjanc, V., Krek, S., Popič, D. (2015): Med ideologijo knjižnega in standardnega jezika. V V. Gorjanc, P. Gantar, I. Kosem in S. Krek (ur.): Slovar sodobne slovenščine: problemi in rešitve. Ljubljana: Znanstvena založba Filozofske fakultete Univerze v Ljubljani.

Granić, J. (2013): Novija hrvatska standardnojezična praksa. V. Požgaj Hadži (ur.): Jezik između lingvistike i politike: 67-89. Beograd: Biblioteka XX vek.

Halilović, S. (2014): Jezička stvarnost u Bosni i Hercegovini. Socjolingwistyka, 28: 121-135.

Haugen, E. (1983): The Implementation of Corpus Planning: Theory and Practice. V J. Cobarrubias, J. A. Fishman (ur.): Progress in Language Planning: International Perspectives: 269-289. Berlin: Mouton de Gruyter.

Jakšić, B. (1996): Ka jeziku mira. Beograd: Forum za etničke odnose.

Klikovac, D. (2008): Jezik i moć. Beograd: Biblioteka XX vek.

Katnić-Bakaršić, M. (2013): Bosanskohercegovačka sociolingivstička previranja. V V. Požgaj Hadži (ur.): Jezik između lingvistike i politike: 113-132. Beograd: Biblioteka XX vek.

Kordić, S. (2010): Jezik i nacionalizam. Zagreb: Durieux.

Langston, K. (1999): Linguistic cleansing: Language purism in Croatia after the Yugoslav break-up. International Politics, 36: 179-201.

Lakić, I. (2013): Jezička slika Crne Gore. V V. Požgaj Hadži (ur.): Jezik između lingvistike i politike: 133-158. Beograd: Biblioteka XX vek.

Lučić, R. (2007): Uvest ću još koju riječ i ozdravit će dušta tvoja!. V J. Granić (ur.): Jezik i identiteti/Languages and Identities: 337-346. Zagreb, 
Split: HDPL.

Lovrenović, I. (2012): Promemorija o (hrvatskoj) jezičnoj politici u Bosni i Hercegovini. Dostopno prek: http://ivanlovrenovic.com/2012/11/promemorija-ohrvatskoj-jezicnoj-politici-u-bosni-i-hercegovini-2/ (26. 12. 2015).

Mićanović, K. (2006): Hrvatski s naglaskom. Zagreb: Disput.

Mihaljević Djigunović, J., Opačić, N., Kraš, T. (2005): Čega se više bojimo: materinskog ili stranog jezika?. V D. Stolac, N. Ivanetić, B. Pritchard (ur.): Jezik u društvenoj krizi: 303-317. Zagreb, Rijeka: HDPL.

Mønnesland S. (2005): Od zajedničkog standarda do trostandardne situacije. V S. Mønnesland (ur.): Jezik u Bosni i Hercegovini: 481-524. Sarajevo, Oslo: Institut za jezik u Sarajevu, Instutut za istočnoevropske i orijentalne studije Oslo.

Mønnesland, S. (2009): Sociolingvistička situacija u Crnoj Gori. V

L. Badurina, I. Pranjković in J. Silić (ur.): Jezični varijeteti i nacionalni identiteti: 125-136. Zagreb: Disput.

Mønnesland, S. (2013): National Symbols in Multinational States: The Yugoslav Case. Oslo: Sypress Forlag.

Numanović, A. (2012): Reprezentacija fenomena „dvije škole pod jednim krovom" u bosanskohercegovačkim štampanim medijima. V S. Madacki, M. Karamehić (ur.): Dvije škole pod jednim krovom. Studija o segregaciji u obrazovanju: 181-216. Sarajevo: Centar za ljudska prava Univerziteta u Sarajevu, Asocijacija Alumni Centra za interdisciplinarne postdiplomske studije. Dostopno prek: http://www.2skole1krov.info/wpcontent/uploads/2013/o2/Dvije-s\%CC\%8Ckole-pod-jednim-krovom.pdf (10. 1. 2016).

Opačić, N. (2014): Novi jezični putokazi. Zagreb: HSN.

Palić, I. (2009): Mogućnosti funkcioniranja triju standardnih jezika (bosanskoga, hrvatskoga i srpskoga) u Bosni i Hercegovini. V L. Badurina, Pranjković, I. in J. Silić., (ur.): Jezični varijeteti i nacionalni identiteti: 111-123. Zagreb: Disput. 
Pančić, T. (2000): Vizantijsko plavo. Vreme 519, 14. 12. 2000. Dostopno prekhttp://www.vreme.com/arhiva_html/519/15.html (13. 1. 2016).

Pašalić Kreso, A. (2008): The war and postwar impact on the educational system of Bosnia and Herzegovina. V S. Majhanovich, C. Fox, A. Pašalić Kreso (ur.): Living together, Education and Intercultural Dialogue: 67-88. Berlin: Springer.

Peti-Stantić, A., Langston K. (2013): Hrvatsko jezično pitanje danas. Zagreb: Srednja Europa.

Peti, M. (2006): Razlikovni rječnici. V M. Samardžija, I. Pranjković (ur.): Hrvatski jezik uXX. stoljeću: 507-530. Zagreb: MH.

Piper, P. (2003): Srpski između velikih i malih jezika. Beograd: Beogradska knjiga.

Požgaj Hadži, V. (2014): Language policy and linguistic reality in former Yugoslavia and its successor states. Inter faculty, 5: 49-91. Dostopno prek: https://journal.hass.tsukuba.ac.jp/interfaculty/article/view/87/155 (13. 1. 2016).

Požgaj Hadži, V., Balažic Bulc, T. (2013): Jezik in moč v spremenjenih družbenopolitičnih okoliščinah. V A. Žele (ur.): Družbena funkcijskost jezika: vidiki, merila, opredelitve: 335-341. Ljubljana: Znanstvena založba Filozofske fakultete.

Pranjković, I. (2008): Sučeljavanja. Zagreb: Disput.

Radovanović, M. (2009): Srpski jezički standard. L. Badurina in dr. (ur.): Jezični varijeteti i nacionalni identiteti: 199-213. Zagreb: Disput.

Samardžija, M. (2015): Pregršt novosti iz jezične kroatistike. Radovi Zavoda za slavensku filologiju, 28-29, 127-129.

Samardžija, M. (2015): Srpsko-hrvatski objasnidbeni rječnik. Zagreb: Matica hrvatska.

Silić, J. (2006): Funkcionalni stilovi hrvatskoga jezika. Zagreb: Disput. 
Silaški, N., Đurović, T., Radić-Bojović, B. (2009): Javni diskurs Srbije. Beograd: Centar za izdavačku delatnost Ekonomskog fakulteta u Beogradu.

Stevanović, M. (2014): Ćirilica vs latinica. Danas, 15. 12. 2014. Dostopno prek: www.danas.rs/danasrs/kultura/cirilica_vs_latinica.11.html?news_id=294252 (13. 1. 2016).

Šipka, M. (2006): Jezik i politika: Sociolingvističke analize. Beograd: Beogradska knjiga.

Šipka, M. (2005): Standardni jezik i jezička politika u Bosni i Hercegovini 1918-1970. V: S. Mønnesland (ur.): Jezik i demokracija: 203-212. Sarajevo: Institut za jezik.

Škiljan, D. (2008): Unutrašnje i vanjsko priznanje jezika. A. Peti-Stantić (ur.): Identitet jezika jezikom izrečen: 79-87. Zagreb: Srednja Europa.

Ustava Republike Srbije. Beograd: Urad za sodelovanje z mediji Republike Srbije (oktober 2006). Dostopno prek: www.ustavni.sud.rs/page/view/sr-LatnCS/70-100028/ustav-republike-srbije (27. 12. 2015).

Vajzović, H. (2001): Savremena jezička situacija u Bosni i Hercegovini komunikativna i simbolička funkcija jezika. S. Mønnesland (ur.): Jezik $i$ demokracija: 79-93. Sarajevo: Institut za jezik. 


\title{
(RE)STANDARDIZATION IN THE VICE OF \\ NATIONAL IDENTITY: THE CASES OF \\ CROATIAN, SERBIAN, BOSNIAN AND MONTENEGRIN
}

\begin{abstract}
Among different functions of linguistic standardization, the unifying, separatist, and prestige functions play a special role. In this paper, we focus on the separatist function, which calls for a redefinition of the status of standard languages. In addition, policy-making plays an important role within this process. Such are often the cases of restandardization or - in other words - the reshaping of an already standardized language; however, on different terms. We present the results of such processes on four successor-languages of the former SerboCroatian, i.e. Croatian, Serbian, Bosnian, and Montenegrin. These underwent numerous (necessary as well as unnecessary) changes following the separation, especially in lexis and phonetics, with significant symbolic value. The reasons for changes are thus external (new sociopolitical order) as well as internal (change in the relation towards the neighboring standard languages, increased interest in linguistic matters, partisanship of individual linguists within institutions, etc.), and in both cases, closely linked to political structures.
\end{abstract}

Keywords: (re)standardization, standard language functions, Croatian, Serbian, Bosnian, Montenegrin

To delo je ponujeno pod mednarodno licenco Creative Commons: Priznanje avtorstva-Deljenje pod enakimi pogoji 4.o.

This work is licensed under the International Creative Commons Attribution ShareAlike 4.0 International License.

http://creativecommons.org/licenses/by-sa/4.0/

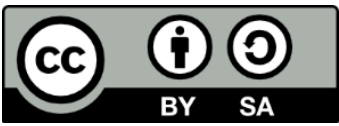

